\title{
SUSAN STANFORD FRIEDMAN
}

\section{Wędrówki po definicjach. \\ Znaczenia terminów „nowoczesny”/ „nowoczesność” / „modernizm”}

Czym jest nowoczesność? Czym jest lub był modernizm? Dlaczego energicznie rozwijające się, multidyscyplinarne pole studiów modernistycznych przepełnione jest tak silnie duchem kwestionowania aktualnych podstaw nauki? Tworzenie definicji to procesy fikcjonalizacji, choć często brzmią jak racjonalna kategoryzacja. A skoro tak, rozpocznę od trzech opowieści, mających charakter alegoryczny, ale osadzonych w moim własnym doświadczeniu badanej dziedziny ${ }^{\mathrm{I}}$.

\section{Opowieść pierwsza: Gdzie się podziali wszyscy buntownicy?}

Wyobraźmy sobie młodą kobietę rozpoczynającą naukę w $1965 \mathrm{r}$. na jednym z amerykańskich uniwersytetów stanowych. Przypomnijmy sobie, jak wyglądały drobnomieszczańskie marzenia takich (białych) dziewczyn z klasy średniej w latach 50.: mokasyny i buty siodłate; spódnice z motywem pudla i gorsetowa sukienka; czirliderki i rozhisteryzowane fanki Elvisa; damskie koledże; samochód kombi i czwórka dzieci. Życie BEZ książek. BEZ sztuki. BEZ celu. BEZ pasji. Konformizm był jedynym celem. Konformizm i materializm. Wówczas. Pierwsze wystąpienia ruchu na rzecz wolności słowa (Free Speech Movement) w Berkeley.

I Ten szkic jest skróconą wersją rozdziału przygotowywanej książki Transnational Modernism: Spatial Poetics, Politics, and the New Modernist Studies [książka pod zmienionym tytułem: Planetary Modernism: Provocations on Modernity Across Timezapowiadana jest na rok 2015 - przyp. tłum.]. Jego krótsza wersja była przeze mnie prezentowana na Uniwersytecie w Coimbrze w Portugalii w maju 2000 r. oraz podczas konferencji Modernist Studies Association (University of Pennsylvania) w październiku 2000 r. Jestem wdzięczna słuchaczom obu odczytów za ich pytania i wsparcie, a także Ricie Felski za twórczą i krytyczną lekturę. 
Sprzeciw. Seks. Trawka. Brody. Przebite uszy. Długie włosy. Styl unisex. Prawa obywatelskie. Wietnam. Feminizm. Prawa dla gejów i lesbijek. Prawa do opieki społecznej. Prawa związkowe. "Czym był modernizm” dla młodego człowieka kończącego studia literatury anielskiej i amerykańskiej w tym gorącym czasie lat 60.? Modernizm był buntem. Modernizm oznaczał „make it new" ${ }^{2}$. Modernizm był sprzeciwem, zerwaniem. Dla samych jego prekursorów. Dla studentów. Modernizm był antidotum na truciznę tradycji, zobowiązania.

\section{Opowieść druga: Czego w rzeczywistości oczekiwał cyberpunk?}

Wyobraźmy sobie starzejącą się uczoną w roku 1995, dobiegającą pięćdziesiątki, otwierającą na uniwersytecie stanowym swoje pierwsze seminarium poświęcone modernizmowi. „Czym był modernizm?” - pyta. Uciekające spojrzenia i cisza. Para z boku kręci się niespokojnie. Ona z podciętymi, fioletowymi włosami i podkreślonymi kohlem oczami. On ubrany w kabaretki i buty na koturnie. Staranny pukiel jedwabistych złotych włosów opada na jego plecy. Wyszczupleni w czerni, o bladych obliczach - jakby cienie samych siebie. Wiedzą, „czym modernizm był”. Modernizm oznacza dla nich elitaryzm. Modernizm to establishment. „Wysoka Kultura" nastawiona przeciwko temu, co niskie, masowe, popularne. Modernizm był nadrzędną fikcją, wzorcową narracją, wielką nadzieją białych. Dla swoich Po-Mo [postmodernistycznych] następców, modernizm jest wrogiem. Postmodernizm jest antidotum na truciznę tradycji, zobowiązania.

\section{Opowieść trzecia: Co ma zrobić biedny student?}

Przysłuchajmy się wymianie zdań między dwoma uczonymi; jednym - siwiejącym, drugim - pobłyskującym łysiną, ale i powagą piastowanego stanowiska. Ona jest krytykiem kultury, on - socjologiem. Dzieci lat 60., nauczyciele w latach 90. Jest rok 1995, skoro ich rękopisy krążą jeszcze pocztą papierową. „Czym był modernizm?" - pytają, oboje uważają go za zjawisko historyczne, ale żadne $\mathrm{z}$ nich nie jest skłonne przyznać, że to zjawisko osta-

${ }^{2}$ Przypominam tu słynne hasło Ezry Pounda i dwóch wpływowych esejów: Harry'ego Levina What Was Modernism? (z książki Refractions: Essays in Comparative Literature, New York 1965, s. 271-295) oraz Maurice'a Beebe'a What Modernism Was (,Journal of Modern Literature” 1974, nr 3, s. 1065-1084). 
tecznie domknięte. Dla obojga modernizm zarazem był i jest. „Czym” jednak był modernizm? Ona wie. To (złudne) zerwanie z przeszłością, z tradycją, ciągłością i porządkiem. To uścisk $\mathrm{z}$ chaosem. To kryzys reprezentacji, fragmentacja, wyobcowanie. To nieokreśloność, zerwanie z pewnikami - materialnymi i symbolicznymi. To poetyka nowoczesności - zmiany. (Tymczasem dla przedstawicieli cyberpunku modernizm nie tyle „jest”, ile stanowi obojętną dla postmodernizmu przeszłość).

On także wie. Modernizm to państwowe planowanie. Modernizm to system totalizacji i centralizacji. Modernizm to racjonalne schematy oświecenia. „Postęp” - „Nauka” - „Rozum”„Prawda”. Modernizm to ideologia post-renesansowej nowoczesności - ideologia podboju. (Tymczasem dla przedstawicieli cyberpunku modernizm wciąż stanowi odradzające się zagrożenie scentralizowanych hegemonii i utopijnych totalitaryzmów).

Moral tych opowieści: Modernizm JEST tylko w wymianie zdań, w której samo słowo znaczy nie tyle różne rzeczy, ile sprawy całkiem odmienne.

Przeciwstawne znaczenia narastające z czasem (opowieść pierwsza i druga) przekształcają się w opozycje istniejące w przestrzeni wiedzy (opowieść trzecia). In toto opowieści wskazują na sytuację zaznaczania się w czasie i przestrzeni tych opozycji. Skończmy jednak z gawędziarstwem i zajmijmy się innym rodzajem sytuacji: parataksą - bezspójnikowym zestawieniem kilku zdań. Parataksa: powszechna strategia estetyczna modernistycznego pisarstwa i sztuki wypracowana, by zakłócić i rozbić konwencjonalne porządkowania, przyczynowość. Parataksa: w nauce o języku przeciwieństwo hipotaksy, a zatem przeciwieństwo hierarchicznego uporządkowania członów syntaktycznych. Parataksa: mechanizm "pracy marzenia sennego" w teorii Freuda, opisujący nieświadome procesy zatajania ekspresji wypieranych, nierozwiązanych lub sprzecznych pragnień.

\section{Parataksa pierwsza:}

A. „Modernizm [...] jest tą sztuką, która odpowiada na porządek naszego chaosu"3.

3 Modernism. A Guide to European Literature (1890-1930), red. M. Bradbury, J. McFarlane, London 1976, s. 27. 
B. „ «Kto mówi nowoczesność, mówi organizacja» - jak zostało zauważone" ${ }^{4}$.

\section{Parataksa druga:}

A. „Jak mogliśmy zauważyć, twórcy modernistycznych dzieł są demistyfikatorami: demaskują absolutyzm, racjonalizm, idealizm - i wszystkie tego typu złudzenia"'.

B. „Nie wydaje mi się, że możemy próbować zrozumieć modernizm, o ile nie przyjrzymy się temu, jak po wielokroć pozornie sam siebie zmuszał - w chwilach, $\mathrm{w}$ których świadomy był swego przełomowego charakteru - do podjęcia zadania projektu oświeceniowego czy filozofii burżuazyjnej, w sposób bezwzględny, na trwałe zmieniający świat" ${ }^{6}$.

\section{Parataksa trzecia:}

A. „Modernizm wydaje się zatem momentem, w którym idea radykalnej i innowacyjnej sztuki, eksperymentalna, technologiczna, estetyczna doskonałość, wyrastające z romantyzmu, przechodzą kryzys - w ramach którego mit, struktura i organizacja $\mathrm{w}$ tradycyjnym sensie rozpadają się, nie tylko z powodów formalnych. Kryzys jest kryzysem kultury"7.

B. „Czym zatem jest «wysoki modernizm»? Najlepiej rozumieć go jako silną - ktoś mógłby powiedzieć: umięśnioną - wersję wiary w naukowy i technologiczny postęp, związany z procesem industrializacji Europy Zachodniej i Ameryki Północnej od około 1830 r. aż do I wojny światowej. W centrum tych przekonań była silna wiara w ciągły, linearny postęp, w rozwój naukowej i technologicznej wiedzy, w rozwój produkcji, w racjonalne projektowanie porządku społecznego, w możliwość zaspokojenia ludzkich potrzeb, ale i także $\mathrm{w}$ rosnące panowanie nad naturą (w tym ludzką naturą) w związku z naukowym rozumieniem praw natury. Wysoki modernizm jest zatem szczególną, szeroką wersją zastosowania pożytków technologicznego i naukowego postępu - zwykle przez państwo - na każdym polu ludzkiej działalności"8.

4 A. Giddens, Foreword, w: NowHere: Space, Time and Modernity, red. R. Friedland, D. Boden, Berkeley 1994, s. XII.

5 R. Caserio, The Novel in England (1900-1950), New York 1999, s. 82.

6 T.J. Clark, Farewell to an Idea: Episodes from a History of Modernism, New Haven 1999, s. 139.

7 Modernism. A Guide to European Literature..., s. 26.

${ }^{8}$ J.C. Scott, Seeing Like a State: How Certain Schemes to Improve the Human Condition Have Failed, New Haven 1998, s. 89-90. 


\section{Parataksa czwarta:}

A. „Być nowoczesnym to znaleźć się w otoczeniu, które obiecuje przygodę, siłę, radość, rozwój, przemianę nas samych i świata - ale równocześnie grozi zniszczeniem wszystkiego, co mamy; wszystkiego, co wiemy; wszystkiego, czym jesteśmy. Nowoczesne środowiska i doświadczenia nie znaja geograficznych, etnicznych, klasowych, narodowych, religijnych ani ideologicznych barier - i w tym sensie nowoczesność jednoczy całą ludzkość. Jest to wszakże jedność paradoksalna, jedność w braku jedności; nowoczesność wciąga nas bowiem $\mathrm{w}$ wir nieustannego rozpadu i ponownych narodzin, sprzeczności i walki, udręki i niepewności. Być nowoczesnym to należeć do świata, w którym - jak powiedział Marks - «wszystko, co stałe, rozpływa się w powietrzu»" .

B. „Najważniejszą figurą w modernizmie jest oddzielenie tego, co statyczne i abstrakcyjne, od tego, co dynamiczne i płynne. Ta figura to Kartezjańskie «ja», abstrakcyjne prawa naturalne Rewolucji Francuskiej, Kantowskie uzasadnienie, nieudany projekt ortodoksyjnego marksizmu, regularne siatki miast, Corbousierowska machine à babiter [maszyna do mieszkania], Habermasowska idealna sytuacja komunikacyjna” ${ }^{\text {Io }}$.

\section{Parataksa piąta:}

A. „Nieodłącznym warunkiem nowoczesności [...] było odrzucenie tych [oświeceniowych] narracji, które zdawały się stanowić silne podpory his-story: antropomorfizmu, humanizmu, prawdy. [...] We Francji takie próby wymagały nade wszystko ponownego włączenia i rekonceptualizacji tego, co pozostawało poza głównymi narracjami, co im umykało z pola widzenia. To inne, co poza, prawie zawsze okazuje się w jakimś sensie [...] kodowane jako kobiece" "II.

B. „,...] nauka, jeśli nie ogranicza się do wypowiadania użytecznych prawidłowości i szuka prawdy, musi uprawomocniać swoje reguły gry. Dlatego też uprawia odnoszący się do jej własnego statusu dyskurs uprawomocniający, zwa-

9 M. Berman, Wszystko, costałe, rozphywa sięw powietrzu, przeł. M. Szuster, Kraków 2006, s. 138.

Io Introduction: Subjectivity and Modernity's Other, w: Modernity and Identity, red. S. Lash, J. Friedman, Oxford 1992, s. 1. Czytamy tam jednak także: „nowoczesność to ruch, płynność, zmiana, nieprzewidywalność” (ibidem). s. 25 .

II A. Jardine, Gynesis: Configurations of Woman and Modernity, Ithaca 1985, 
ny filozofią. Kiedy ów metadyskurs ucieka się wprost do takiej czy innej wielkiej narracji, jak dialektyka Ducha, emancypacja podmiotu myślącego lub pracującego, rozwój bogactwa, to naukę, która odwołuje się do nich, aby siebie uprawomocnić, będziemy nazywali «nowoczesnością». [...] była to narracja Oświecenia, kiedy to bohater wiedzy pracował w imię celu etyczno-politycznego, to jest powszechnego pokoju” ${ }^{\text {2 }}$.

\section{Parataksa szósta:}

A. „Jeśli można mówić o «modernizmie» jako głównym ruchu w zachodniej literaturze (i sztuce w ogóle) pierwszej połowy XX wieku, byłbym zdania, że można także mówić o «modernistycznej formie» jako terminie, który opisywałby zespół stylistycznych praktyk [...]: (1) estetyczną samoświadomość; (2) symultaniczność, jukstapozycję czy «montaż» $[. ..] \mathrm{i}$ «fragmentaryzację»; (3) paradoks, niejasność i niepewność; oraz (4) [...] świadomą sztuczność, odbiegającą od znanej rzeczywistości, zrywającą z podstawowymi funkcjami języka i konwencjonalnymi formami [...]; szok, naruszenie zasad ciągłości, element de-kreacji i kryzysu [...]" 'з3.

B. „Określone schematyczne różnice $[. .$.

modernizm

romantyzm/symbolizm

forma

(spójna, zamknięta)

cel

plan

hierarchia

mistrzostwo/logos

sztuka przedmiotowa/

dzieło skończone

totalizacja/synteza

obecność postmodernizm

patafizyka/dadaizm

antyforma

(niespójna, otwarta)

gra

przypadek

anarchia

wyczerpanie/cisza

proces/performance/

happening

dekonstrukcja/antyteza

brak

I2 J.F. Lyotard, Kondycja ponowoczesna, przeł. M. Kowalska, J. Migasiński, Warszawa 1997, s. 19-20.

I3 M. DeKoven, Rich and Strange: Gender, History, Modernism, Princeton 1991, s. 6. 


$\begin{array}{ll}\text { centralizacja } & \text { rozproszenie } \\ \text { gatunkowość } & \text { intertekstualność } \\ \text { hipotaksa } & \text { parataksa } \\ \text { signifiant } & \text { signifié } \\ \text { wielka narracja } & \text { mikronarracja } \\ \text { genitalny/falliczny } & \text { polimorficzny/ } \\ & \text { androgeniczny } \\ \text { źródło/przyczyna } & \text { różnica }(\text { differance }) / \text { ślad } \\ \text { metafizyka } & \text { ironia } \\ \text { określoność } & \text { nieokreśloność } \\ \text { transcendencja } & \text { immanencja" }{ }^{\text {I4. }} .\end{array}$

\section{Parataksa siódma:}

A. „Nowoczesność wiąże się zatem nie tylko z bezwzględnym zerwaniem ze wszelkimi historycznymi uwarunkowania$\mathrm{mi}$, ale także charakteryzuje się niekończącym procesem własnych wewnętrznych pęknięć i fragmentacji” " 5 .

B. „Wiara «w linearny postęp, niezbite prawdy i racjonalne planowanie idealnego społecznego porządku» dzięki znormalizowanym procedurom wiedzy i produkcji była szczególnie silna. Modernizm dał w efekcie dzieła zarazem "pozytywistyczne, technokratyczne i racjonalistyczne», jak i będące rezultatem działań awangardowej elity urbanistów, artystów, architektów, krytyków i innych stróżów dobrego smaku" ${ }^{16}$.

Morał pierwszy: Jako terminy wypracowane przez dyskurs naukowy pojęcia „nowoczesny”, „nowoczesność”, „modernizm” wytwarzają krytyczną Wieżę Babel, kakofonię kategorii, które stają się tym bardziej bezużyteczne, im bardziej niekonsekwentnie są stosowane. Możemy je postrzegać jako parodię krytycznego dyskursu, w ramach którego wszyscy mówią jednocześnie w języku pozbawionym wspólnych znaczeń. Gdy terminy opisują

${ }^{{ }_{4}}$ I. Hassan, The Dismemberment of Orpheus: Toward a Postmodern Literature, Madison 1992, 267-268.

I5 D. Harvey, The Condition of Postmodernity: An Enquiry into the Origins of Social Change, Oxford 1989, s. 10-12.

I6 Ibidem, s. 35. Kończę ten łańcuch parataktycznych par cytatami z tego samego autora, by podkreślić istnienie tej trudnej do wyjaśnienia sprzeczności w obrębie prac jednej osoby. 
zupełnie różne lub przeciwstawne rzeczy, ich użycia okazują się całkowicie zagrażać idei uprawiania nauki/ nauczaniu.

Morał drugi: Jako sprzeczne terminy uniemożliwiające uzgodnioną definicję pojęcia „nowoczesny”, „nowoczesność”, „modernizm" stanowią żyzną glebę dla badań, w ramach których coraz częściej plenią się wciąż nowe znaczenia. Jako parodia racjonalnego dyskursu, sprzeczności podkreślają takie sposoby wytwarzania znaczeń, których prawdopodobnie nie da się zatrzymać i które wykluczają spójność czy ujednolicenie dyskursu. Ich użycia zapewniają trwanie naukowego / pedagogicznego projektu, którego głównym zadaniem jest podtrzymywanie ciągłości badań, zabezpieczenie - w skrócie - właśnie swojego własnego trwania.

Modernizmy to jedna rzecz, ale modernizm jako całkowita sprzeczność to co innego. Definicje rodzą mnogość w każdym akcie próby uspójnienia znaczenia w obrębie określonych granic. Definicje oznaczają objęcie, związanie, ustabilizowanie. Często jednak ich efektem jest płynność, stan destabilizacji w niekończących się przekształceniach, deformacjach i poprawkach, których wymagają zmieniające się potrzeby danego momentu. Definicje odzwierciedlają punkt widzenia swoich twórców. Wyłaniają się z przestrzenno-czasowego kontekstu momentu ich powstawania. Obsługują różne potrzeby i zainteresowania. Radykalnie zmieniają się w czasie i przestrzeni. Definicje przybierają maskę synchronicznej abstrakcji, zawsze jednak pozostają przedmiotem diachronicznych dziejów i przestrzennych geografii ciągłości, zmiany i różnicy. Nie oczekuję zatem ustalenia czy odnalezienia stałego znaczenia takich terminów jak „nowoczesny”, „nowoczesność”, „modernizm”. Spodziewam się różnic.

Sprzeczne znaczenia to jednak inny problem, który przekracza kwestię różnicy, sprzeciwu wobec totalizujących metanarracji, prowizorycznych, strategicznych, płynnych i przysposabianych na potrzeby danej sytuacji znaczeń - co charakteryzuje najbardziej użyteczne definicyjne ćwiczenia. Nie dążę do stałości czy mnogości. Zabiegam raczej o otwarte zmierzenie się ze sprzecznym statusem znaczeń ${ }^{17}$.

${ }^{17}$ Inaczej, niż czynię to w tym miejscu, zauważano już sprzeczności charakterystyczne dla prób rozstrzygnięcia tej różnicy zdań. Zob. na przykład książkę Rity Felski The Gender of Modernity (Cambridge 1995), w której w zwięzły sposób uzasadnia ona swoje aprobatę dla studiów kulturowych, które opisują zachodnią 
Opowieści dotyczyły problematycznego terminu „modernizm”, ale nieubłaganie doprowadziły nas do sieci słów - „modernizm” [modernism] i jego rodzeństwa: „nowoczesny” [modern], „nowoczesność" [modernity] i „modernizacja” [modernization]. Nie tylko znaczenie pojęcia kwestionuje stałość, ale także jego gramatyczne i semantyczne aspekty. Słowo „nowoczesny” [ modern] jest zarazem rzeczownikiem i przymiotnikiem, mającym znaczenie deskryptywne bądź normatywne. Różne sufiksy ustawiają słowo w rozmaitych gramatycznych funkcjach, którym przysługuje różna semantyczna treść. Sufiks „-ość” wyrazu „nowoczesność” [modernity $]$ - ograniczający słowo „nowoczesny” [modern] do rzeczownika - nadaje mu status przedmiotu bądź stanu, który odróżnić można od innych przedmiotów bądź stanów. Sufiks „-izm” wyrazu „modernizm” [modernism $]$ przekształca rzeczownik „nowoczesny” [ modern] w ruch, zazwyczaj zorganizowany wokół systemowej filozofii, polityki, ideologii czy estetyki. Sufiks „-izacja” wyrazu „modernizacja” [modernization $]$ oznacza proces, rewolucję bądź ewolucję z jednego stanu w drugi, $\mathrm{z}$ „nowoczesnością” [modernity] jako stanem osiąganym dzięki „modernizacji” $[\text { modernization }]^{18}$.

Co jednak z kuzynami tego rodzeństwa - „prenowoczesnym” [premodern], „ponowoczesnym” [postmodern], „ponowoczesnością” [postmodernity], „postmodernizmem” [postmodernism]? Jak przedrostki „pre-” i „post-” zmieniają źródłowe znaczenia? Na jakich obszarach są te kategorie wyraźnie odrębne, skoro wydają się zaledwie modyfikacjami terminów "nowoczesny” $[$ modern $]$, „nowoczesność” [modernity], „modernizm” [modernism]? ${ }^{19} \mathrm{~W}$ jaki sposób ta cała rodzina terminów zależy od ich

nowoczesność od oświecenia do początków XX w. (s. 12-13); książkę Bernarda Yacka The Fetishism of Modernities: Epochal Self-Consciousness in Contemporary Social and Political Thought (Notre Dame 1997), w której omawia on cztery różne koncepcje nowoczesności (filozoficzną, socjologiczną, polityczną i estetyczną) i przekonuje, że przy wszystkich różnicach łączy je „nacisk na innowacyjność i sprzeciw wobec tradycyjnych autorytetów” (s. 35); Marshall Berman w książce Wszystko, co stałe, rozpływa się w powietrzu przekonuje zaś, że sprzeczności są efektem ewolucji w ramach nowoczesności (op.cit.).

I8 Nie analizowałam terminu „modernizacja” [modernization], ponieważ w rozumieniu jego podstawowego znaczenia daje się zauważyć daleko silniejszy konsensus, niż ma to miejsce w przypadku terminu „nowoczesność” [modernity]; choć dyskusji o przyczynach, efektach i polityce modernizacji nie brakuje.

I9 Związek między terminami „nowoczesny” [ modern]/ "ponowoczesny” [postmodern]/ „modernizm” [modernism]/ „postmodernizm”[postmodernism] jest tak problematyczny, jak znaczenia samego słowa „nowoczesny” [ modern] i zdecydowanie przekracza ramy tego eseju. Wielu teoretyków społecznych używa 
w różnych kontekstach używanych antonimów - „tradycyjny” [traditional $]$, „klasyczny” [ classical $]$, „starożytny” [ancient $]$, „feudalny” [ feudal $]$, , agrarny” [ agrarian], ,dawny” [past]?

Dawno, dawno temu krytycy literaccy i krytycy sztuki używali terminu „modernizm” - szczególnie z zaznaczeniem wielkiej litery („Modernizm”), czy też wzmacniając go przymiotnikiem „wysoki” („Wysoki Modernizm”) - by opisać ruchy w sztuce, które były z sobą luźno powiązane i rozwijały się równolegle. Natomiast teoretycy społeczni, historycy, socjologowie używali terminów "nowoczesny” $[$ modern $]$, „nowoczesność” [modernity] i ,modernizacja” [ modernization] do opisania historycznych okresów, warunków i procesów. Obecnie jednak takie granice między dyscyplinami przestały obowiązywać, ponieważ różne formy źródłowego pojęcia obsługują różne cele.

Symptomatycznie i prowokacyjnie interdyscyplinarne pismo „Modernism/Modernity” łączy dwa z tych terminów, tak jakby ukośnik między nimi był - z jednej strony - znakiem ich wymienności $\mathrm{i}-\mathrm{z}$ drugiej strony, pomimo tego - ich nieusuwalnej separacji. Ukośnik jest sygnałem trwałego połączenia i rozłączenia. To kolejna sprzeczność, która domaga się uwagi. Czy istnieje taki ukośnik, który zarazem oddziela i łączy terminy „nowoczesny” $[$ modern $] /$ „nowoczesność" [modernity]/ „modernizm” [modernism]/ „modernizacja” [ modernization] zarówno z wyrazami im pokrewnymi, jak i z antonimami?

Psychoanalityczny objazd: Romans rodzinny skłóconego rodzeństwa i kuzynostwa przyciąga psychoanalizę do tej defi-

pojęć „ponowoczesny” [postmodern] czy „postmodernizm” [postmodernism], by opisać zerwanie z oświeceniową nowoczesnością, traktując estetyczny demontaż nowoczesności w wieku XIX i XX jako wczesną zapowiedź zmiany, która miała nastąpić później i bardziej powszechnie w XX stuleciu. To zatem, co wielu innych badaczy postrzega jako „nowoczesność" [ modernity] i „modernizm” [modernism], jest tylko ogniwem „postmodernizmu” [postmodernism]. Zob. na przykład książki Lyotarda Kondycja ponowoczesna czy Harveya The Condition of Postmodernity. Z powodu sprzeczności terminologicznych ich krytyka społeczna modernizmu jest często błędnie rozumiana jako atak także na estetykę modernizmu. Problem z ustaleniem, czy postmodernizm stanowi intensyfikację modernizmu, czy też radykalne z nim zerwanie jest komplikowany przez różne użycia terminów „nowoczesnośc”" [modernity]/ „modernizm” [modernism], „ponowoczesność" [postmodern]// „postmodernizm” [postmodernism]. Być może najbardziej znaczące zerwanie z nowoczesnością ma miejsce obecnie - dzięki rewolucji naukowej rozpoczętej procesami komputeryzacji i związanymi z nimi efektami przyspieszonej globalizacji. 
nicyjnej dyskusji. Rozdźwięk znaczeń - szczególnie opozycja znaczeń - otwiera możliwość psychodynamicznego odczytania, które poszukuje irracjonalnych i ukrytych procesów represji, powrotu i przeniesienia $\mathrm{w}$ ramach studiów modernistycznych pomiędzy dyscyplinami, jako że te procesy odbijają nierozwiązane kompleksy w ramach samej nowoczesności.

Scena analizy jest według Freuda psychodynamiczna, jest sceną, na której analizowany i analityk przenoszą stłumione pragnienia i kompleksy pozornie dawno już zapomniane. Przeniesienie (i przeciwprzeniesienie) w psychoanalizie wymaga powtórzenia tego, co nie może być świadomie zapamiętane, odtworzenia tego, co stłumione, czemu wciąż świadomie nie udało się stawić czoła. Praktyka kliniczna Freuda zakładała celowe indukowanie przeniesienia, by dramat powtórzenia mógł stać się podstawą samej psychoanalizy $^{20}$.

Terminologiczne tarapaty studiów modernistycznych mogą być efektem procesu przeniesienia, w ramach którego niejako przyłapuje się uczestników dyskusji na powtarzaniu nierozwiązanych sprzeczności - obecnych i przeważnie stłumionych w samej nowoczesności. Opowieści i parataksy zaprezentowane w poprzednich częściach tego szkicu celowo inscenizowały ten dysonansowy dramat, aby przekierować nasze zainteresowanie z dyskusji o znaczeniach rozważanych terminów ku analizie tego, co przede wszystkim wytwarza ten dysonans. Adaptuję tu i łączę pogląd Julii Kristevej o „tekstualnej nieświadomości”, Fredrica Jamesona koncepcję „politycznej nieświadomości” oraz Shoshany Felman psychoanalityczne interpretacje twórczości Edgara Allana Poego i Henry'ego Jamesa w książce The Turn of the Screwer. Szczególnie gorąca i trudna do rozstrzygnięcia dyskusja dotycząca literackiego znaczenia - przekonuje Felman może być postrzegana jako scena przeniesienia, jako scena oporu i powtórzenia. Taka scena - często mająca charakter zaciekłej konfrontacji - skrywa „nieświadomość”, która może być postrzegana psychoanalitycznie jako „wywiad chorobowy”, który

${ }^{20}$ Zob. Freuda Technikę terapii (Warszawa 2007), szczególnie teksty W kwestii dynamiki przeniesienia (przeł. R. Reszke) oraz Przypominanie, powtarzanie i przepracowanie (przeł. A. Czownicka). W książce The Fetishism of Modernities, B. Yack opisuje postmodernistyczne zainteresowanie nowoczesnością jako „obsesję” i „fetyszyzm”, który prowadzi do nieuprawnionych totalizacji epoki, co pozostaje w niezgodzie z deklarowaną obroną petits récits i heterogeniczności.

${ }_{21}$ Zob. szczególnie: J. Kristeva, Desire in Language, przeł. T. Gora, A. Jardine, L.S. Roudiez, New York 1980, s. 36-91; F. Jamesona The Political Unconscious: Narrative as a Socially Symbolic Act, Ithaca 1981; Literature and Psychoanalysis: The Question of Reading: Otherwise, red. S. Felman, Baltimore 1980, s. 94-207; S. Felman Lacan and the Adventure of Insight, Cambridge 1987, s. 27-51. 
pozwala ujawnić skrywane kompleksy, stłumione i nierozwiązane w oryginalnych tekstach literackich. Odwołanie do koncepcji politycznej nieświadomości Jamesona pozwala zauważyć, jak skrajnie odmienne punkty widzenia kodują nie od razu oczywistą i zamierzoną politykę.

Na podobnych zasadach multidyscyplinarne studia modernistyczne prowokują terminologiczne dyskusje, które przywracają sprzeczności uprzednio obecne w tych terminach i zjawiskach, do których one się odnoszą. Co zatem kryje się w rozroście znaczeń terminów „nowoczesny”, „nowoczesność” i „modernizm”? Jak dysonanse i opozycje mogą powodować rozdźwięk, który zachęca do podjęcia interpretacji? Co ten rozdźwięk mówi nam zarówno o sprzecznościach i skomplikowaniu znaczeń i polityki zjawisk, do których te terminy się odnoszą, jak i ich o zmienności w różnych historycznych momentach i przestrzennych uwarunkowaniach?

Ścieżka przez Krainę Czarów Studiów Modernistycznych: Jak wejść do i być może wydobyć się z labiryntu sprzeczności i opozycji w ramach studiów modernistycznych? Proponuję dwie drogi wędrówki po definicjach: pierwszą - gramatyczną i filozoficzną, drugą - polityczną i kulturową. Borykają się one z kwestią opozycyjnych znaczeń w nawzajem dopełniający się sposób. Nie rozstrzygając niczego, odsłaniają one różne kierunki powstawania sprzecznych znaczeń, różne kierunki negocjowania znaczeń w definicyjnej dyskusji, każda na swój charakterystyczny sposób. Nie rozstrzygając i nie zamykając niczego, wyjaśniają, co zagraża tej dyskusji i dlaczego pytanie o to, co ją powoduje, może uwolnić od silnie zakorzenionej wierności częściowym jedynie znaczeniom.

Droga gramatyczna/filozoficzna: Ta ścieżka rozpoczyna się od rozpoznania różnicy między nominalnym i relacyjnym trybem definiowania - czyli traktowania terminów (rodzeństwa „nowoczesny” / „nowoczesność” / „modernizm”) jako rzeczowników z określoną, dającą się zdefiniować treścią (dyskutowalną jednak) i postrzeganie ich jako przymiotników implikujących możliwość porównania $\mathrm{z}$ innymi stanami istnienia ${ }^{22}$. Różnica między tymi podejściami do zagadnień definiowania wyjaśnia niektóre z opozycji w ramach studiów modernistycznych, jednak nie wszyst-

${ }^{22}$ Jestem wdzięczna Noel Carroll za uświadomienie mi nominalnego i relacyjnego trybu definiowania na terenie filozofii. Wzbogaciłam jej spostrzeżenia o wymiar gramatyczny, akcentujący rozróżnienie między rzeczownikami i przymiotnikami w definicjach pojęć „nowoczesny” / „nowoczesność” / „modernizm". 
kie. Sprzeczność istnieje nie tylko między tymi trybami, ale także w obrębie każdego $\mathrm{z}$ nich ${ }^{23}$.

\section{Tryb nominalny - rzeczownik}

W ramach definicji nominalnych, słowa „,nowoczesny”/ „nowoczesność” / "modernizm” oznaczają określoną własność: szereg cech określający konkretne rzeczowe stany i przestrzenno-czasowe położenia. Nie oznacza to jednak, że musi panować pełna zgoda co do tej określonej własności. Jednak dla tych, którzy pracują na rzecz nominalnej struktury czy zabiegają o nią, definicyjne przedsięwzięcie skupia się na takim powiązaniu kategorii, aby wytworzyć szereg znaczeń, do których można by przekonać innych. Niezależnie od tego, czy takie przedsięwzięcia miałyby charakter kanoniczny czy rewizyjny, zakładają one nominalny status pojęć modernizm czy nowoczesność: są to rzeczowniki, z określonym znaczeniem, choćby i spierać się o ich potencjalną siłę wyjaśniającą.

Nominalne dyskusje o terminach "nowoczesny” / "nowoczesność” / "modernizm” dążą do określenia tego, co specyficzne, nawet za cenę definicyjnych rozdźwięków czy wprost sprzeczności między różnymi dyskursami naukowymi i dziedzinami. Najbardziej radykalny rozdźwięk nominalnych znaczeń istnieje w przepaści, jaka dzieli nauki społeczne i humanistyczne. Teoretycy społeczni, politolodzy, socjologowie i antropolodzy zazwyczaj podążają za historykami Europy, którzy wyróżniają epoki antyczną, średniowieczną, wczesnonowoczesną i nowoczesną; i co za tym idzie definiują epokę „,nowoczesną” jako okres zerwania ze średniowiecznymi instytucjami i jako zespół poglądów, które zostały wypracowane w tym czasie. „Nowoczesność” w tym kontekście oznacza określony zespół historycznych uwarunkowań, które pojawiły się w kulturze zachodniej (w tym rewolucję przemysłową, ekonomiczną i polityczną ekspansję na inne kontynenty, przejście do kultury miejskiej, rozwój świado-

${ }^{23}$ Choć część uczonych odwołuje się raczej do wybranego trybu, wielu używa obydwu - zob. np. Anthony'ego Giddensa nominalne deklaracje w książce Nowoczesność i tożsamość: „ja” ispołeczeństwo w epoce późnej nowoczesności (przeł. A. Szulżycka, Warszawa 2010, s. 29): „Terminem «nowoczesność» będę się posługiwał w bardzo ogólnym znaczeniu jako kategorią odnoszącą się do instytucji i wzorów zachowań, których początki sięgają końca europejskiego feudalizmu, chociaż znaczący wzrost ich realnego wpływu na losy świata zaznaczył się z całą intensywnością dopiero w XX wieku. Za odpowiednik «nowoczesności» można z grubsza przyjąć «świat uprzemysłowiony», pamiętając jednak, że industrializm nie jest jej jedynym wymiarem instytucjonalnym". W trybie relacyjnym pisze jednak: „Nieodłączne dla pojęcia nowoczesności jest zestawienie go z pojęciem tradycji”" (A. Giddens, Konsekwencje nowoczesności, przeł. E. Klekot, Kraków 2008, s. 36). 
mości narodowej, wzrastającą rolę mieszczaństwa). Zgodnie z tą periodyzacją filozofowie często traktują teorie rozumu w dziełach Locke'a, Kanta i Hegla jako uosobienie wyraźnie nowoczesnego sekularyzmu i humanizmu. Dla politologów nowoczesność często oznacza wykształcenie określonych rodzajów systemów politycznych, na drodze od feudalizmu do monarchii ograniczonej, demokracji i różnych autokracji; dla ekonomistów - rodzaje rynków, kapitału czy klasy pracującej; dla antropologów - wykorzenienie czy (wymuszoną) asymilację tradycyjnych kultur $\mathrm{w}$ procesie podboju przez inne narodowości, systemy rynkowe czy bardziej „zaawansowane” technologie. Teoretycy postkolonialni często wiążą nowoczesność z imperializmem i narodowymi walkami o niezawisłość od kolonialnej władzy. I tak dalej ${ }^{24}$.

Tymczasem w naukach humanistycznych nowoczesność i modernizm najczęściej są wiązane raczej z radykalnym zerwaniem niż z najwyższym uosobieniem post-renesansowego, oświeceniowego humanizmu i towarzyszących mu formacji w kulturze zachodniej. Artyści i pisarze - zgodnie z tym punktem widzenia - ustanawiali awangardową zmianę, dostrzegłszy przenikliwie i najwcześniej zasadnicze znaczenie i przyszłe konsekwencje epistemologicznych, ontologicznych, politycznych, technologicznych, demograficznych, kulturowych i estetycznych zmian. Określenie czasu, miejsca i postaci tego wiązanego ze stylem modernistycznym zerwania raz się pokrywają, innym razem znacznie się różnią. Krytycy poezji modernistycznej często wskazują na poetykę fragmentu, parataksy, obrazu, idiosynkratycznych rytmów i wzorców brzmieniowych. Krytycy sztuki często skupiają się na zerwaniu z realizmem, zaznaczającym się we wzmożonym zainteresowaniu formą, szczególnie kształtami i płaszczyznami czysto geometrycznymi. Historycy architektury często zwracają uwagę na surowy, funkcjonalny minimalizm projektów Bauhausu jako wyraz nowoczesności i jej estetyki w epoce maszyny. Dla historyków muzyki przyjęcie prymitywizmu i atonalności przez takich kompozytorów jak Strawiński może określać modernizm. Krytycy mediów zwracają uwagę na zasadniczy wpływ nowych mechanicznych środków reprodukcji (fotografii, radia, kina, telewizji). I tak dalej ${ }^{25}$.

${ }_{24}$ Zob. np.: A. Giddens, D. Harvey, J.F. Lyotard, D. Scott, B. Yack, J. Habermas, Modernity versus Postmodernity, „New German Critique” 1981, nr 22, s. 3-14; idem, The Philosophical Discourse of Modernity, New York 1987; A. Appdurai, Modernity at Large: Cultural Dimensions of Globalization, Minneapolis 1996; Model Modernity: An Introduction to Modern Societies, red. S. Hall et al., Malden 1996.

${ }_{25}$ Zob. na przykład Modernism (red. M. Bradbury, J. McFarlane, London 1976) oraz The Modern Tradition (red. R. Ellmann, Ch. Feidelson, New York 1965), 
Modernizm w obrębie nauk humanistycznych jest najczęściej rozumiany jako swobodnie powiązane ruchy i indywidualności w sztuce i literaturze, które odznaczyły się i miały wpływ na ukształtowanie świadomości i kondycji nowoczesnej w Europie, Wielkiej Brytanii i Stanach Zjednoczonych ${ }^{26}$. Periodyzacja - jakkolwiek rozbieżności mogą występować na odmiennych subpolach - różni się zasadniczo od tej wysuwanej przez teoretyków społecznych i historyków. Co więcej, uosobieniem nowoczesności dla nauk społecznych jest dokładnie to, przeciwko czemu według nauk humanistycznych - nowoczesność występuje.

Na pierwszy rzut oka ta definicyjna przepaść może wydawać się arbitralna, będąca efektem różnego usytuowania dziedzin oraz izolacjonizmu w ramach akademii, a także braku szczególnego zainteresowania dla definicyjnych badań. Kilka czynników podaje w wątpliwość taki punkt widzenia.

Po pierwsze, opozycji między naukami społecznymi i humanistycznymi nie daje się łatwo zlekceważyć jako arbitralnej czy nieznaczącej, ponieważ takie dziedziny, jak antropologia kulturowa, historia, geografia, teoria polityczna, dziennikarstwo, studia feministyczne i studia postkolonialne są multidyscyplinarne $\mathrm{i}$ interdyscyplinarne $\mathrm{i}$ istnieją na przecięciu tych dwóch rodzajów nauk, ponieważ obejmują zarówno zagadnienia repre-

zbiory, które pomimo oczywistych braków zachowują istotne miejsce w definiowaniu znaczenia i kanonu estytycznego modernizmu. Bardziej współczesne, definicyjne podejście zob.: A. Eysteinsson, The Concept of Modernism, Ithaca 1990; M. Norris, Modernist Eruptions, w: The Columbia History of the American Novel, red. E. Elliot, New York 1991, s. 311-330; M. Perloff, Modernist Studies, w: Redrawing the Boundaries: The Trans-formation of English and American Literary Studies, red. S. Greenblatt, G. Gunn, New York 1992, s. 154-178; M. Calinescu, Five Faces of Modernity, Durham 1987; P. Nicholls, Modernisms: A Literary Guide, Berkeley 1995; The Gender of Modernism: A Critical Anthology, red. B.K. Scott, Bloomington 1990 (tu szczególnie teksty Clark i Jardine).

${ }^{26}$ Związanie modernizmu i nowoczesności z Europą i Stanami Zjednoczonymi w naukach humanistycznych nie tylko wyklucza nie-zachodnie regiony, ale prowokuje także problemy z samą „kulturą zachodnią” - by wspomnieć na przykład o marginesach genderowych, rasowych, geograficznych, etnicznych, czy też o całych narodach (hiszpańskim, portugalskim, brazylijskim) lub regionach (Bałkanach, Europie Wschodniej, Karaibach). Zob. np.: Genders, Races, and Religious Cultures in Modern American Poetry, 1908-1934, New York 2001; J.A. Boone, Libindinal Currents: Sexuality and the Shaping of Modernism, Chicago 1998; S. Benstock, Women of the Left Bank: Paris, 1900-1940, Austin 1986; S. Gilbert, S. Gubar, No Man's Land: The Place of the Woman Writer in the Twentieth Century, New Haven 1988-1994; S. Gikandi, Writing in Limbo: Modernism and Caribbean Literature, Ithaca 1992; H.A. Baker, Jr., Modernism and the Harlem Renaissance, Chicago 1987; P. Gilroy, The Black Atlantic: Modernity and Double Consciousness, Cambridge 1993; A. Gambrell, Women Intellectuals, Modernism, and Difference: Transatlantic Culture, 1919-1945, New York 1997; N.J. Davison, The Concept of Modernism in Hispanic Criticism, Boulder 1966. 
zentacji, teorii, organizacji społecznej, stosunków władzy czy badań empirycznych, jak i kwestie dotyczące formacji twórczych. W związku z tym opozycyjne znaczenia terminów „nowoczesny”, „nowoczesność”, „modernizm” często współistnieją w ramach niektórych dyscyplin, dziedzin i akademickich instytucjonalnych jednostek.

Po drugie, w ostatnich trzydziestu latach wraz z re-legitymizacją interdyscyplinarności granice między dyscyplinami i dziedzinami wiedzy stawały się coraz bardziej nieszczelne. Takie między-dyscyplinowe działania nie tylko zaowocowały hybrydycznością studiów, ale i wprowadziły pewne zakłopotanie. Na przykład w zbiorze Modernist Antbropology Marco Manganaro (który jest zatrudniony na wydziale literatury) doprowadza do spotkania antropologów i badaczy literatury, by przeanalizować wzajemne związki między modernizmem literackim i modernistyczną antropologią $\mathrm{w}$ pierwszej połowie $\mathrm{XX} \mathrm{w}$. W rezultacie otrzymujemy pasjonujący, interdyscyplinarny opis przenikania estetycznych i etnograficznych przedsięwzięć epoki. Termin „modernizm” jednak płynnie przechodzi między opozycyjnymi znaczeniami - od racjonalnego porządku odnajdywanego $\mathrm{w}$ antropologii Boasa i Malinowskiego do anarchistycznego nieporządku odkrywanego w awangardowej sztuce i poetyce. To wahanie w żadnym miejscu zbioru nie zostaje wprost wskazane, jest powielane w wielu poszczególnych szkicach. Książka zatem raczej wzmacnia niż rozwiązuje definicyjne problemy w sposób oczywisty objawiające się w nakładaniu często niezauważanych, odmiennych znaczeń terminu „modernizm” w teorii społecznej i estetyce.

By wskazać inny jeszcze przykład - geograf David Harvey otwiera swoją wpływową książkę The Condition of Postmodernity odwołaniem do Baudelaire'owskiego określenia życia nowoczesnego jako „przemijającego, zmiennego, przypadkowego i ulotnego", cytuje krytyka literackiego Marshalla Bermana mówiącego o modernizmie i nowoczesności z książki Wszystko, co stałe, rozphywa się w powietrzu, a następnie przytacza paradygmatyczne wersy modernistyczne W.B. Yeatsa z wiersza Drugie przyjście: „Wszystko w rozpadzie, w odśrodkowym wirze;/ Czysta anarchia szaleje nad światem" ${ }^{27}$. Harvey, silnie zakorzeniony w konwencjonalnie literackim rozumieniu „modernizmu” jako zerwania, prowadzi swój opis postmodernizmu w powiązaniu z modernizmem (czy szczególnie z tym, co nazywa Wysokim Modernizmem) oraz z oświeceniowym projektem „rozwoju ra-

\footnotetext{
${ }_{27}$ Por. D. Harvey, The Condition of Postmodernity..., s. 10.
} 
cjonalnych form organizacji społecznych i racjonalnych koncepcji” ${ }^{28}$, pokazuje szczegółowo formalne pęknięcia w ramach modernistycznej epistemologii, ontologii i reprezentacji. Następnie Harvey cytuje sławne schematyczne tabele Ihaba Hassana, akcentujące zerwanie między modernizmem i postmodernizmem zerwanie thumaczone przez niego rzekomym przyswojeniem przez modernizm Kartezjańskiej podmiotowości i oświeceniowej racjonalności ${ }^{29}$. W swej świetnej książce, usytuowanej niejako ponad podziałem dyscyplin w ramach studiów modernistycznych, Harvey płynnie prześlizguje się pomiędzy „anarchią” i „organizacją” jako trybami definiowania Wysokiego Modernizmu, sporadycznie tylko wspominając o napięciu między nimi.

Po trzecie, obstawanie przy arbitralnych podziałach na dyscypliny przesłania to, co jest wspólne dla wszystkich nauk społecznych i humanistycznych - mianowicie nacisk na zerwanie z przeszłością, dyskusję o polityce nowoczesności/modernizmu oraz dominujący eurocentryzm. Teoretycy społeczni i krytycy sztuki zaciekle sprzeczają się między sobą o znaczenie nowoczesności i modernizmu w debatach, w których metodologiczne podziały ujawniają się słabiej. Nowoczesność (lub modernizm) jest wyzwalająca czy opresyjna, progresywna czy regresywna? Czy jej idee i ideały powodują wykluczenie jednych ze względu na korzyść innych, czy też otwierają się na możliwości rozszerzania, włączania w przestrzeni wolności i różnorodności? Pytania są podobne, niezależnie od tego, czy odnoszą się do kwestii rewolucji i niewolnictwa, czy do pytań o awangardę i kulturę masową. Niektórzy bronią nowoczesności/modernizmu, inni - atakują. Podstawą wszystkich tych nominalnych dyskusji jest problematyczne założenie, że nowoczesność/modernizm zapoczątkowano w kulturze zachodniej, a następnie podjęto i imitowano w mniej wyrazistej formie $\mathrm{w}$ pozostałych częściach świata. Jeśli wziąć pod uwagę te podobieństwa, rozdźwięk pomiędzy znaczeniami terminów „nowoczesny” / „nowoczesność” / ,modernizm” jest znacząco osłabiony.

Nominalne podejście do definiowania terminów „nowoczesny” / "nowoczesność” / „modernizm” nadmiernie ufa w możliwość uzgodnienia znaczeń tych terminów jako rzeczowników o określonej treści: szereg cech istniejących w obrębie łatwo dostrzegalnych granic znaczenia, przestrzeni i czasu. Choć jeśli się przyjrzeć bliżej, można zauważyć pewien konsensus, czy to pomiędzy dyscyplinami, czy w obrębie nich. Ta podatność no-

\footnotetext{
${ }_{28}$ Ibidem, s. 12.

29 Ibidem, s. 42-44.
} 
minalnego podejścia do tworzenia różnorodnych, czy nawet opozycyjnych znaczeń podważa nazywającą funkcję rzeczownika.

\section{Tryb relacyjny - przymiotnik}

Relacyjne podejście do znaczenia terminów „nowoczesny” / „nowoczesność” / "modernizm” poszukuje raczej ukrytej struktury niż jawnych treści pojęcia. Zamiast lokować nowoczesność w określonym czasie post-renesansowej czy post-oświeceniowej kultury zachodniej, definicja relacyjna akcentuje stan radykalnego zerwania i przyspieszonych zmian ${ }^{3}$. To, co nowoczesne czy modernistyczne, zawdzięcza swoje znaczenie negacji, swoistej rebelii przeciwko temu, co już raz było czy przypuszczalnie było. Podobnie jak przymiotniki, takie jak ,wysoki” czy „duży”, uzyskują znaczenie w odniesieniu do innych przymiotników, takich jak „niski” czy „mały”, relacyjne znaczenie terminu „nowoczesny” (i jego rodzeństwa) istnieje w obrębie dwuczłonowej opozycji z tym, co „tradycyjne”. Termin nie tyle ma uniwersalne znaczenie, ile raczej zyskuje znaczenie wobec swojej ukrytej opozycji. Podczas gdy tradycja zapowiada przyszłość jako kontynuację przeszłości, nowoczesność upomina się o nieustanne przekraczanie przeszłości jako konieczny warunek przyszłości.

By rzecz wypowiedzieć w trybie relacyjnym, nowoczesność opowiada się po stronie „Teraz” - teraźniejszość i jej przyszłość stawiają opór przeszłości, szczególnie tej najbliższej. Taka sytuacja ustanawia kult tego, co nowe, który z kolei wytwarza znaczenie tradycji, wobec której deklaruje niezależność. Paradoksalnie taka tradycja - czy też świadomość takiej „tradycji” - może zaistnieć tylko w momencie rebelii przeciwko niej.

Właśnie dlatego, że relacyjna definicja nie dąży do stałości definicji nominalnych, nowoczesność nie musi przynależeć do określonego szeregu instytucjonalnych, ideologicznych czy estetycznych cech, które pojawiły się w post-renesansowej kulturze zachodniej i rozprzestrzeniały się wzdłuż ścieżek imperium jako wyblakłe kopie zachodniego geniuszu. Zamiast tego poszczególne nowoczesności mogą pojawić się tam, gdzie powieje wiatr radykalnego zerwania, gdzie rozgorzeją radykalne zmiany, czy też gdzie rozleje się świadomość nowości.

$3^{\circ}$ Rozwijając „skalarny” model nowoczesności w książce Broaching a Cultural Logic of Modernity, Eric Rothstein posługuje się trybem relacyjnym, by opisać społeczeństwa jako „gorące”, „ciepłe” lub „chłodne”, w zależności od tego, jak silne i w jakim stopniu dominujące okazało się zjawisko zerwania w danym czasie i miejscu. Jego relacyjne podejście do periodyzacji uwzględnia heterogeniczność w obrębie danej epoki. 
Relacyjne podejście do definiowania terminów „nowoczesny”/ "nowoczesność" /,modernizm” prowokuje jednak tyleż pytań, ile ofiarowuje odpowiedzi. Po pierwsze, niemożliwe jest nieustanne zerwanie czy rewolucja, ponieważ taka zmiana szybko się instytucjonalizuje. To, co ma swój początek w różnorodnych aktach rebelii przeciwko powszechnie obowiązującym hegemoniom, staje się - dzięki odniesionemu sukcesowi - szybko skodyfikowanym systemem. Marginesy stają się centrami. W świecie intelektualistów $i$ artystów na przykład outsiderzy przechodzą do centrum, rebelianci tworzą establishment. Nowa oświeceniowa nauka, która obaliła porządek symboliczny oparty na religijnej wierze, stała się hegemoniczną normą opartą na wierze w Rozum. Awangardowi artyści (impresjoniści, postimpresjoniści, kubiści, przedstawiciele ekspresjonizmu abstrakcyjnego) - początkowo witani pobłażliwym uśmiechem - uważani są teraz za wielkich mistrzów, których prace stanowią podstawę muzealnych ekspozycji i sprzedawane są za bajeczne sumy. To, co na początku było odrzucane, zakazywane, ośmieszane i często nieczytane (to przypadek Freuda i Joyce'a), staje się dla wielu najwyższym ucieleśnieniem epoki, podstawową lekturą $\mathrm{w}$ dziedzinie historii idei i literatury. Jak przekonuje Raymond Williams, antyburżuazyjne początki modernizmu zostały stłumione w momencie, gdy modernizm stał się kanonem po II wojnie światowej ${ }^{15}$. Zgodnie z zasadą zerwania: im bardziej powszechna staje się nowoczesność, tym silniej okazuje się skodyfikowana i autorytatywna, a to z kolei podważa jej reputację zapalnej rebelii i zmiany. Zinstytucjonalizowane, awangardowe zerwanie to nowy establishment, unieważniany przez kolejne nowe awangardy. Istotny sukces nowoczesności (i jej modernistycznych realizacji) polega na wyraźnej instytucjonalizacji swojego własnego końca - w imperatywach ponowoczesności.

Po drugie, przy swoim obstawaniu po stronie tego, co nowe, relacyjna nowoczesność jest w sposób nieunikniony częścią dynamiki generacyjnej. Nowoczesność buntuje się przeciw swoim prekursorom po to, by przeciw niej wystąpili jej następcy - to kolejna odsłona romansu rodzinnego. Nowoczesność zajmuje niełatwe miejsce między przed-nowoczesnością, którą przezwycięża, i po-nowoczesnością, która przezwycięża ją samą. Bez szansy na pełną stabilizację istnieje w środku przyimkowego łań-

${ }^{3}$ R. Williams, The Politics of Modernism: Against the New Conformists, red. T. Pinkney, New York 1989, s. 32-36. Pierwszy esej w tym zbiorze zatytułowany When Was Modernism? stanowi rewizyjne nawiązanie do wcześniejszych prac Harry'ego Levina i Maurice'a Beebe'a. 
cucha - definiowana przez swą pozycję „po" tym, co tradycyjne, i „przed” tym, co postmodernistyczne.

Po trzecie, ten łańcuch przyimków każe podać w wątpliwość relacyjne założenie o uwolnieniu od historii. (Samo)świadoma nowoczesność - rozumiana jako radykalne zerwanie z najbliższą przeszłością - odrzuca zasadę historycznej ciągłości i ewolucji przez swoje obstawanie po stronie punktu otwarcia, nowości i rewolucji. Zatem taka nowoczesność kwestionuje swoją własną produkcję jako historyczną. Tymczasem historia wytwarza zarówno zmiany, jak i ciagłość; nowe formacje kulturowe i instytucjonalne nowoczesności same są produktem historycznego procesu.

Co więcej, relacyjne pojęcie nowoczesności dba tylko o bunt wobec najbliższej przeszłości, często przeskakując nad głowami wcześniejszych generacji i odwołując się do bardziej odległej przeszłości, w której odnajduje inspirację dla bieżącej rebelii. By uzasadnić to odrzucenie, stosuje się mylne, heurystyczne, a czasem nawet demonizujące odczytania swoich poprzedników - jak to miało miejsce zarówno w przypadku modernistów (niezbyt precyzyjnie) krytykujących wiktoriańskich realistów za epistemologiczną i psychologiczną naiwność, jak i postmodernistów (niezbyt precyzyjnie) ograniczających modernistów do ram oświeceniowych wielkich narracji. Jak sugerował Paul de Man, powołując się na Nietzschego, nowoczesność pociagga za sobą rodzaj „bezwzględnego zapominania”, „pragnienie wymazania wszystkiego, co było wcześniej" ${ }^{2}$. Jako taka relacyjna świadomość nowoczesności jest oparta na historycznej iluzji - uporczywym wymogu „make it new” manifestacyjnie odrzucającym prawa do obecności przeszłości w teraźniejszości i przyszłości. Im silniej nowoczesność zapewnia o swej absolutnej nowości, tym silniej przemilcza swoje zakorzenienie w przeszłości. Im silniej historia jest tłumiona, tym silniej powraca, by obnażyć iluzoryczną i ideologiczną mitologię nowości.

Relacyjne podejście do definiowania pojęć „nowoczesny”/ „nowoczesność”/ „modernizm” dopuszcza możliwość uzgadniania znaczeń terminów jako strukturalną zasadę radykalnego zerwania - w jakiejkolwiek formie by ona nie wystapiła. Uwolnienie od stałości rzeczownika obiecuje, że relacyjna definicja okaże się zdolna wytworzyć porozumienie zarówno pomiędzy dyscyplinami, jak i w ich obrębie. Jednak przy bliższym spojrze-

${ }^{2}$ P. de Man, Literary History and Literary Modernity, w: idem, Blindness and Insight, Minneapolis 1983, s. 147-148. Por. także różne wersje tego argumentu $\mathrm{w}$ książkach: R. Felski, The Gender of Modernity; D. Harvey, The Condition of Postmodernity..., s. 36-38; B. Yack, The Fetishism of Modernities..., s. 12-13. 
niu wychodzą na jaw podobne sprzeczności, co przy nominalnym podejściu. Podobnie jak rzeczownik - to, co „nowoczesne”, w przymiotnikowej formie prześlizguje się płynnie pomiędzy znaczeniami zakorzenionymi w możliwości i niemożliwości wymogu „make it new”. Jeśli przymiotnikowa forma „nowoczesności” oznacza zarazem rewolucję i ewolucję, zarazem zerwanie $\mathrm{z}$ historią i powrót do niej, jaka jest jej moc opisowa?

Zarówno nominalne, jak i relacyjne znaczenia terminów „nowoczesny”/ "nowoczesność”/ „modernizm” borykają się ze sprzecznością i odsyłają do zjawisk, które oznaczają zarazem powstawanie hegemonii i ich rozpad, tworzenie wielkich narracji i ich demontowanie. I jako rzeczownik, i jako przymiotnik „nowoczesność” jest terminem, który sam siebie zwalcza, terminem, który sam rozmontowuje swoją definicję, terminem, który potwierdza zasadę nieokreśloności.

Podsumowując, gramatyczne/filozoficzne podejście do projektów definicyjnych potwierdza zawsze częściowy charakter i zwodniczą naturę każdej definicji, która skupia się jedynie na nominalnych lub tylko relacyjnych znaczeniach nowoczesności. Nowoczesność nie jest wyłącznie stałym szeregiem cech objawiających się w danym miejscu i czasie, jak na przykład europejskim oświeceniem czy XX-wieczną awangardą w sztuce. Nie daje się też nowoczesności sprowadzić jedynie do zasady zerwania. Nowoczesność najkorzystniej jest rozumieć jako szereg znaczeń, które obejmują zarazem specyfikę rzeczownika i relacyjną strukturę przymiotnika. Co więcej, takie podejście, które zespala oba sposoby definiowania, podpowiada, że znaczenie nie daje się sprowadzić ani do powstawania hegemonii, ani do ich rozpadu. Nowoczesność natomiast zawiera w sobie zarówno dośrodkowe, jaki i odśrodkowe siły sprzeczności i nieredukowalnych zależności. Problemu nie sprowadzałabym zatem do kwestii historycznego okresu ani utopijnej dialektyki. Kładłabym raczej nacisk na znaczenie tworzone granicznie, pomiędzy - w akcie takiej negocjacji, która zestawia $\mathrm{z}$ sobą i przeciw sobie sprzeczne procesy powstawania i rozmontowywania, dostrzegając ich wzajemną konieczność.

\section{Droga polityczna/kulturowa}

Wędrówkom gramatycznym/filozoficznym brakuje historycznej i geograficznej kontekstualizacji, brakuje namysłu nad wytwa- 
rzaniem i zużywaniem się znaczenia, brakuje uwagi poświęconej kwestiom władzy $i$ instytucjonalizacji wiedzy $w$ ramach projektów definicyjnych. Definicje nie powstają i nie funkcjonują w abstrakcyjnym kosmosie czystego rozumu i arbitralnego znaczenia. (Tymczasem dla językoznawców i filozofów dekontekstualizowanie definicji ma swoje częściowe uzasadnienie tylko w wypadku ich zakwestionowania). Tekstualna nieświadomość definicyjnej dyskusji to także polityczna nieświadomość. Należy zatem takie dyskusje wprowadzić w ramy szeroko rozumianych studiów kulturowych, w konteksty historyczne, globalne i porównawcze.

Powinniśmy postawić pytanie: kto tworzy określone szeregi znaczeń terminów „nowoczesny”/ „nowoczesność”/,modernizm"? Dla jakich odbiorców? Z jakiej pozycji i z jakiego punktu widzenia w określonym czasie i miejscu? Dla jakich celów i ze względu na jaki możliwy efekt? W jaki sposób nowoczesność była i wciąż okazuje się zespołem kulturowych formacji, złożonych $\mathrm{z}$ różnorodnych elementów i na różne sposoby funkcjonujących ujawniających się na różne sposoby w różnym czasie i miejscu, $\mathrm{z}$ różnym także efektem? Jak stosunki władzy warunkują wytwarzanie, rozpowszechnianie i recepcję konkurencyjnych znaczeń? Mówiąc najkrócej, jak kwestie władzy i polityki warunkują samo pojęcie nowoczesności i historyczne zjawiska, do których ten termin się odnosi? Na tych pytaniach studia kulturowe się skupiają.

Studia modernistyczne wydaja się wytwarzać trzy różne konfiguracje takich definicji: binarną, kolistą i metonimiczną. Rozpoznanie tych trzech zasad może pomóc ujawnić stosunki władzy w obrębie procesów instytucjonalizacji wiedzy.

\section{Binarność}

Sam typowy akt definiowania jest wynikiem binarnej relacji włączania i wyłączania (inkluzji i ekskluzji). Jest uzależniony od tego, kto definiuje, włączając pewne zjawiska do kategorii „nowoczesny”/ „nowoczesność” / „modernizm”, inne zjawiska zaś pomijając. Z definicji. Akty definicyjne ustanawiają teorie, wyznaczają mapy, określają centrum, marginesy. Próby ustanowienia terenów pogranicznych (w opozycji do stałych rozgraniczeń) znacząco przyczyniają się do poszerzenia zasięgu definicji, ale w żaden sposób nie usuwają problemu wyraźnego oddzielenia w procesie definiowania pewnych zjawisk od innych, które nie mieszczą się w definiowanej kategorii. Pisząc o tworzeniu kanonu (czyli rodzaju czynności definicyjnych w historii literatury, sztuki i religii), Toni Morrison zauważał: 
Gmach kanonu jest jak gmach imperium. Fortyfikacje kanonu są jak fortyfikacje narodowe. Dyskusje o kanonie, niezależnie od ich miejsca, natury i zasięgu [...] oznaczają starcie kultur. Z ujawnieniem wszystkich partykularnych interesów ${ }^{33}$.

Weźmy na przykład typowe dla teorii społecznej pojęcie nowoczesności jako wynalazku kultury zachodniej, ujawniające się w stwierdzeniach czołowego socjologa nowoczesności, Anthony'ego Giddensa:

Kiedy bowiem mówimy o nowoczesności, mamy na myśli przekształcenia instytucjonalne, których geneza leży na Zachodzie. W jakim stopniu nowoczesność jest specyfiką Zachodu? Odpowiadając na to pytanie, musimy rozważyć różne, analitycznie rozłączne cechy nowoczesności. Z perspektywy ugrupowań instytucjonalnych w rozwoju nowoczesności szczególne znaczenie mają dwa różne kompleksy organizacyjne: państwo narodowe oraz system kapitalistycznego sposobu produkcji. Oba sięgają korzeniami specyficznych uwarunkowań historii europejskiej i nie mają w zasadzie odpowiedników ani w poprzedzających epokach, ani w innych układach kulturowych. Jeżeli razem udało im się rozprzestrzenić na cały świat, to dzięki wytworzonej przez siebie mocy. Żadne inne, bardziej tradycyjne formy społeczne nie potrafiły się tej mocy oprzeć na tyle, by zachować całkowitą autonomię i stać na zewnątrz globalnych tendencji rozwojowych. Czy nowoczesność widziana z perspektywy sposobów życia promowanych przez te dwa potężne czynniki transformacyjne jest specyficznie zachodnim projektem? Na tak postawione pytanie otwarcie trzeba powiedzieć „tak”34.

Jaki obszar wyznacza ta Giddensowska definicja, odzwierciedlająca zachodni punkt widzenia, typowy dla socjologów pokroju autora Konsekwencji nowoczesności - specjalistów w dziedzinie zachodniego społeczeństwa i historii? Czyż zaskakuje nas, że bez dostatecznej wiedzy o cywilizacjach Azji, Afryki i nie-anglofońskiej Ameryki, definicyjna binarność inkluzji/ekskluzji daje w efekcie stanowisko bez reszty eurocentryczne, a także znacznie silniej nominalne niż relacyjne? (Nie). Taki eurocentryzm jest powszechny wszędzie tam, gdzie pisarz sławi (jak Habermas) lub krytykuje (jak Harvey) zachodnią nowoczesność. Zupełnie poza zasięgiem pozostaje natomiast taki model globalizacji, który oparty jest na badaniach centrum i peryferii, w ramach które-

33 T. Morrison, Unspeakable Things Unspoken: The Afro-American Presence in American Literature, „Michigan Quarterly Review” 1989, nr 28, s. 8.

34 A. Giddens, Konsekwencje nowoczesności..., s. 123. 
go osiągnięcia kultury zachodniej są eksportowane, a peryferia je przyswajają i przepisują. Zupełnie poza zasięgiem pozostaje tu także określenie stopnia, w jakim zachodnie formy nowoczesności wypracowane na gruncie zachodnich społeczeństw, mają związek z nie-zachodnimi innymi (z Innym wyobrażonym przez zachodnią kulturę, ale także $\mathrm{z}$ realnymi, różnorodnymi innymi poza Zachodem). Zupełnie poza zasięgiem pozostaje tu wreszcie samo wytwarzanie różnych nowoczesności przez różne historie nie-zachodnich społeczeństw.

\section{Kolistość}

Gidensowska definicja nowoczesności eksponuje zarówno problem hermeneutycznego koła, jak i binarnej inkluzji i ekskluzji35. Definiowanie epok historycznych czy ruchów w sztuce i literaturze podlega tu kolistemu procesowi. Cechy "nowoczesnego"/ „nowoczesności” / „modernizmu” często są identyfikowane w ramach tego podejścia dzięki wskazywaniu na szczególne jakości zjawiska, które wcześniej już włączono w ramy danej kategorii. Mówiąc inaczej, definicyjne „mapowanie” polega na uprzednim wyznaczeniu granic, które jest ściśle związane z przekonaniami i punktem widzenia tworzącego taką mapę.

Weźmy na przykład historię literatury modernizmu. Periodyzacja, kanonizacja i wskazywanie definiujących cech modernizmu są zawsze związane z zespołem założeń, ludzi i/lub działań, których dobór zależy od istniejących uprzednio założeń danego okresu. I tak Hugh Kenner oznajmia, że uchodźczy internacjonalizm jest podstawową cechą definiującą Wysoki Modernizm i dlatego bierze pod uwagę jedynie takich pisarzy jak Pound, Eliot i Joyce, by udowodnić swe twierdzenie. Na tej podstawie przekonuje, że Williams, Faulkner i Woolf są "prowincjonalnymi” czy „regionalnymi” pisarzami, nie modernistycznymi. Gdyby bowiem włączył tych pisarzy w ramy swoich zainteresowań, jego uogólnienia dotyczące modernizmu musiałyby być inne. Zmieniłby się także jego koncept modernistycznego internacjonalizmu, gdyby włączył pisarzy z Afryki, Ameryki Południowej i Azji $3^{6}$.

Przykład Renesansu Harlemu jest bardziej jeszcze uderzający. Literatura, sztuka, muzyka Afroamerykanów - tworzone

35 Na temat krytyki aplikacji takiego podejścia w historii literatury zob. np.: C. Nelson, Repression and Recovery: Modern American Poetry and the Politics of Cultural Meaning, 1910-1945, Madison 1989, s. 9-12; Fredric Jameson, op.cit, s. $27-28$.

${ }^{36} \mathrm{~W}$ tym miejscu odwołuję się przede wszystkim do tekstu Hugh Kennera, The Making of the Modernist Canon („Chicago Review” 1984, nr 34, s. 49-61). 
w Harlemie w latach 20. i 30. - są zupełnie nieobecne na typowych mapach modernizmu. Nie pojawiają nawet tak okazjonalnie, jak kobiety modernistki (Woolf czy Stein). Prymitywizm Picassa, epoka jazzu Fitzgeralda, Eliotowski Sweeney, Faulknerowskie Południe - wszystkie one przynależą do kanonicznych elementów zainteresowań studiów modernistycznych. Trudno wśród nich natomiast odnaleźć pierwszych twórców jazzu, czarnoskórych artystów zwracających się do wyobrażonej (albo realnej) Afryki, piosenkarzy bluesowych i folkowych porzucających wiejskie Południe na rzecz miejskiej Północy w czasach Wielkiej Migracji na początku XX w., czy żołnierzy wracających z bagażem brutalnych doświadczeń I wojny światowej. Ich język i eksperymenty z rytmem, afrykańskie mity, parodystyczne imitacje, rewolucyjny zapał i samo-identyfikacja z tym, co nowe, nie wydały się warte uwzględnienia w większości historii literackiego modernizmu, nawet przez tych historyków, którzy swą uwagę skupiali raczej na analizach formalnych eksperymentów, strategii cytowania, mitycznych analogiach, ironii niż na tworzeniu kolejnych definicji. Ponieważ Renesans Harlemu jest zasadniczo nieobecny w tekstach, w których historycy literatury podejmowali wysiłek wskazywania definicyjnych cech modernizmu, nieobecne są także poszczególne postaci afroamerykańskiej nowoczesności ${ }^{37}$.

\section{Metonimiczność}

Kolejną formą polityki definicji jest identyfikacja pewnych jakości ze względu na całość. Ta metonimiczna substytucja jest szczególnie rozpowszechniona $\mathrm{w}$ ustanawianiu dominujących cech historycznych uwarunkowań nowoczesności czy estetycznych konstelacji modernizmu. Według jednych Locke i Rousseau są najwyższymi wcieleniami oświeceniowej nowoczesności; zdaniem innych, Joyce jest ikoną modernizmu. Na podobnej zasadzie, jedni mogą opisywać zachodnią nowoczesność w terminach rosnącej roli burżuacji, demokracji i nauki, z kolei inni definiują modernizm za pomocą terminów utopijnego społecznego plano-

37 Ta nieobecność zostaje choć w części zredukowana przez te historie literatury, które włączają czarnoskórych pisarzy w krajobraz zróżnicowanego modernizmu, choć trzeba zauważyć, że niektórzy krytycy wciąż dokonują takich rozdziałów, włączając tylko te elementy sztuki Afroamerykanów, które przyswoiła sztuka tworzona przez białych twórców. W tej sprawie zob. np.: J. De Jongh, Vicious Modernism: Black Harlem and the Literary Imagination, New York 1990; M. Torgovnick, Gone Primitive: Savage Intellectuals, Modern Lives, Chicago 1990; M. North, The Dialect of Modernism: Race, Language, and Twentieth-Century Literature, New York 1994; L. Doyle, Bordering the Body: The Racial Matrix of Modern Fiction and Culture, New York 1994; S. Gubar, Racechanges: White Skin, Black Face in American Culture, New York 1997. 
wania czy poetyki zerwania. Wspólna dla tych wszystkich definicyjnych uogólnień jest heurystyczna skłonność do opisywania całości w terminach, które z perspektywy historycznej wydają się najbardziej wpływowymi czy znaczącymi składnikami. W ten sposób takie kategorie jak nowoczesność czy modernizm jednoczą różne formacje kulturowe, włączając ich specyfikę w obręb definicyjnych granic uprzywilejowanego metonimicznie elementu. Te rozważania ponownie zwracają naszą uwagę na pytanie o to, kto wytwarza te metonimiczne narracje. Kogo i co pominięto? $\mathrm{Z}$ jakich powodów?

Tendencja binarnych, kolistych i metonimicznych aktów definicyjnych do reprodukowania gry stosunków władzy w obrębie instytucji wiedzy może w pewnym stopniu prowadzić do potwierdzenia potrzeby epistemologicznej anarchii - wyrugowania wszystkich tego typu periodyzacyjnych kategorii. Problematyczna historia prób definiowania nie powinna jednak - według mnie doprowadzać do takiego wniosku. Raczej, jak pisze Jameson: „Problem periodyzacji i jej kategorii, które z pewnością dotknął współcześnie kryzys [...], wydaje się tyleż nieredukowalny, co niedostateczny w ramach studiów kulturowych" ${ }^{8}$. Bez kategorii historycznych, stajemy przed podejściem do wiedzy wymagającym pewnych form selekcji, a te - rzecz jasna - nigdy nie są politycznie neutralne, jak to miało miejsce w przypadku heurystycznych konstrukcji historycznych narracji. Bez pewnych definicyjnych kategorii polityka wyboru zostałaby jeszcze silniej zepchnięta na margines, byłaby jeszcze słabiej widoczna.

Biorąc pod uwagę nasze, wskazywane tu, zapotrzebowanie na definicyjne kategorie, jakkolwiek niedoskonałe by one nie były, co zatem może zaoferować droga polityczna/kulturowa? Przyglądałam się - nieodłącznym wszelkim definicyjnym działaniom - binarnym, kolistym i metonimicznym problemom nie dlatego, że wprowadzają w ślepą uliczkę, ale raczej dlatego, że umożliwiają takie badania, które prowadzą bezpośrednio w samo centrum dialogicznych znaczeń terminów „nowoczesny”/ „nowoczesność”/ „modernizm”. Wskazują także na rozpoznanie, że terminy same są historycznymi konstruktami - z własną historią, funkcją i efektem, podatnymi na interpretację i krytykę. Różne konfiguracje nowoczesności odzwierciedlają różne punkty

$3^{8}$ F. Jameson, op.cit., s. 28. 
widzenia swych twórców, obsługują różne interesy i mają różne konsekwencje. To dlatego powracamy do kwestii polityki by zapytać, jak stosunki siły nakierowują nas nie tylko na same dzieła kultury nowoczesności, lecz także na ich późniejsze odczytania.

Ta wędrówka - bocznymi drogami opowieści, parataksy, objazdu, aforyzmu i kolażu - ma swój koniec. Stawiłam skutecznie opór pokusie, by zaproponować moją własną, kolejną definicję „nowoczesności” i „modernizmu”, by inni badacze mogli o niej dyskutować lub ją zlekceważyć. (Opór nigdy nie jest łatwy. Zniewalająca siła przyciągania ustalonego znaczenia zdaje się chwilami przemożna). Usiłowałam natomiast skierować moją uwagę na procesy i modele kwestionowania definicyjnych ustaleń.

W ten sposób dochodzimy do takiej konkluzji. Definicyjne rozdźwięki mają swoje znaczenie. Te różnice nie powinny być lekceważone jako przypadkowe czy arbitralne, jako zwykły efekt historii rozwoju dyscyplin czy semantycznych nieporozumień. Nie powinny być także oddalane zwodniczymi argumentami nieredukowalnego pluralizmu. W rzeczywistości, pluralizacja, która spotkała terminy „nowoczesność” i „modernizm”, niesie z sobą ryzyko zamaskowanego przywrócenia modelu centrum - peryferia, w którym hegemoniczna norma jest w sposób zamaskowany właśnie uprzywilejowana wobec marginalnych wariantów ${ }^{39}$.

Drogi gramatyczna/filozoficzna oraz polityczna/kulturowa, które badałam, podpowiadają, że opozycyjne znaczenia terminów „nowoczesny”/ „nowoczesność” / ,modernizm” wskazują na zarazem dialogiczny i sprzecznościowy charakter przenikania się historycznego powstawania zjawisk, do których odnoszą się te terminy. Porządek i jego zakłócenie są symbiotycznie konieczne, by każdy z nich mógł zachować swoje rozpoznawalne znaczenie. Centrum rodzi się w swoim własnym rozproszeniu. Wielkie narracje nowoczesności ustanawiają swoje radykalne demontaże. Siła życiowa nowoczesnego chaosu okazuje się jego porządkiem. Impuls porządku okazuje się produktem chaosu. Modernizm wymaga tradycji wyrażającej się w zasadzie „make it

39 Zob. np. książkę Nichollsa Modernisms; liczba mnoga w jej tytule sugeruje heterogeniczność, ale jej treść poświęcona jest omówieniu w dwunastu rozdziałach zachodniego, białego, męskiego modernizmu oraz kobiecego modernizmu w jednym rozdziale zatytułowanym At a Tangent: Other Modernisms. Tymczasem odejście od liczby pojedycznej w definiowaniu „nowoczesności” i „,modernizmu” powinno raczej oznaczać takie badanie zjawisk, które brałoby pod uwagę ich historyczną i geograficzną specyfikę w transnarodowej i globalnej skali. 
new”. Tradycja powstaje tylko jako rebelia przeciw samej sobie. Wędrówki po definicjach, po znaczeniach terminów „nowoczesny” / „,nowoczesność” / „modernizm” rozpoczynają się i kończą próbą zrozumienia specyfiki tych sprzeczności.

\section{Przet. Tomasz Cieślak-Sokołowski}

\section{SUSAN STANFORD FRIEDMAN \\ Definitional Excursions: The Meanings of Modern/ Modernity/Modernism}

The main task of the present article is to characterize the changing perspectives in the description and definition of modernism and modernity in a reciprocal relationship of these two categories. The creation of definitions is described here as a processes of fictionalization with a generational viewpoint of scholars. Moreover, the article indicates the difference between a nominal and a relational mode of defining and the question of institutionalization of knowledge within the framework of definition projects. Such research perspectives lead to the conclusion about dialogical and at the same time contradictory character of historical formations of phenomena to which the studied terms allude.

Keywords: modernity, modernism, modernist studies.

Susan Stanford Friedman - profesor anglistyki w University of Wisconsin. Jest autorką takich książek jak Psyche Reborn: The Emergence of H.D. (1981, 1987), Penelope's Web: Gender, Modernity, H.D.'s Fiction (1990) oraz Mappings: Feminism and the Cultural Geographies of Encounter (1998). W roku 2015 ma się ukazać jej książka Planetary Modernism: Provocations on Modernity Across Time. Była prezesem Modernist Studies Association w latach 2011-2012. 